\section{Synthesis of a CGRP Receptor Antagonist}

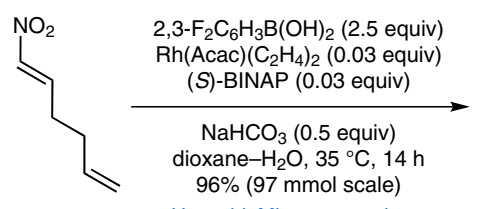

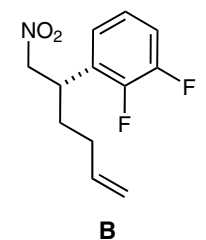

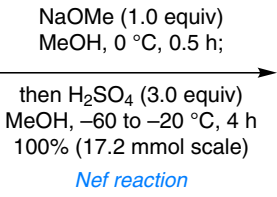<smiles>C=CCC[C@H](C=O)c1cccc(F)c1F</smiles>

C

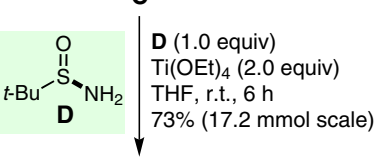

Key words

CGRP receptor antagonist

Hayashi-Miyaura reaction

asymmetric conjugate addition

intramolecular Heck reaction

Ellman-Davis amine synthesis

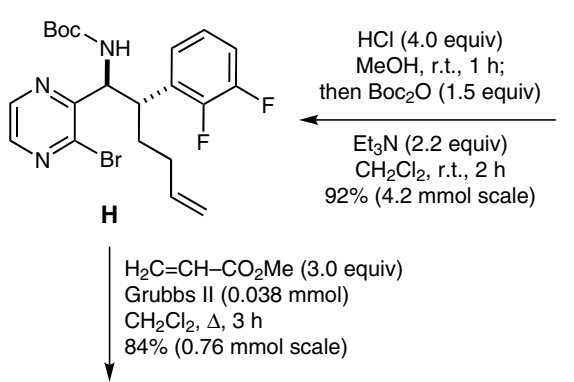

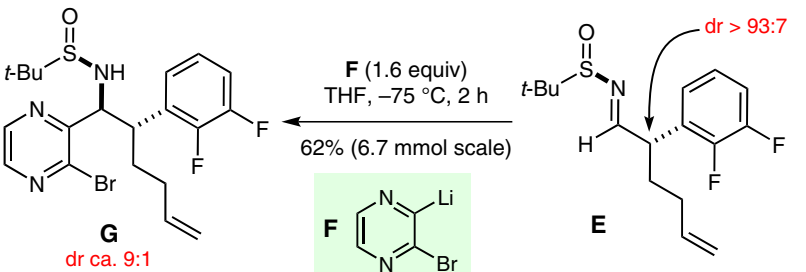<smiles>COC(C)=CCCC[C@H](c1cccc(F)c1F)C(NC(=O)OC(C)(C)C)c1nccnc1Br</smiles>
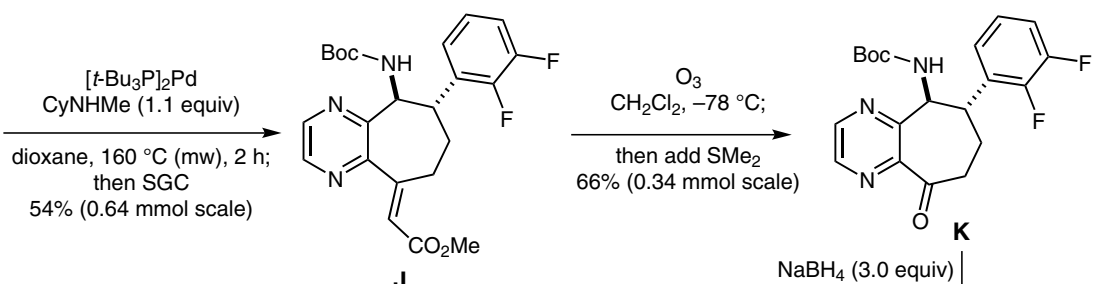

$\mathrm{mp}$ not reported

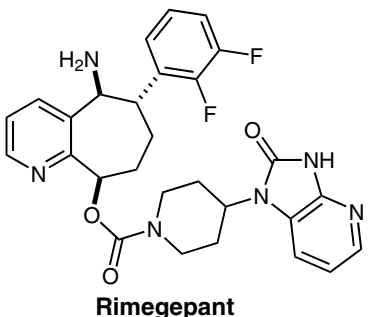<smiles>[M]OC(=O)N1CCC(n2c(=O)[nH]c3ncccc32)CC1OC1CC[C@@H](c2cccc(F)c2F)C(N)c2nccnc21</smiles>

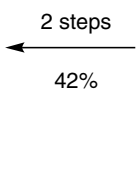

$\mathrm{NaBH}_{4}$ (3.0 equiv) $46 \%(0.23 \mathrm{mmol}$ scale $)$ + diastereoisomer (40\%) separate by SGC<smiles>O=C(NC1c2nccnc2C(O)CC[C@H]1c1cccc(F)c1F)OCc1ccccc1</smiles>

Significance: The target molecule $\mathbf{M}$ is a calcitonin gene-related peptide (CGRP) receptor antagonist that is of interest for the treatment of migraine. It is one of four analogues of rimegepant that were prepared by a common strategy featuring the use of a Hayashi-Miyaura asymmetric conjugate addition $(\mathbf{A} \rightarrow \mathbf{B})$ and Ellman-Davis protocol $(\mathbf{E} \rightarrow \mathbf{G})$ to set two of the three stereogenic centers.
Comment: Attempts to construct the sevenmembered ring from I by an intramolecular Heck reaction were thwarted by the rearrangement of the exocyclic alkene product to a trisubstituted alkene. This alkene isomerization was suppressed in part by addition of an ester group in $\mathbf{J}$.

SYNFACTS Contributors: Philip Kocienski

Synfacts 2016, 12(3), 0223 Published online: 16.02.2016

Dol: 10.1055/s-0035-1561242; Reg-No.: K00316SF 